Arab World English Journal (AWEJ) Volume 12. Number4 December 2021

DOI: https://dx.doi.org/10.24093/awej/vol12no4.16

Pp. 224-242

\title{
Aggressive Language in Literature: A Pragmatic Approach
}

\author{
Hanan Abdul-kareem Kadhim \\ Department of English \\ College of Education For Women, University of Baghdad, Baghdad, Iraq \\ Wafaa Sahib Mehdi Mohammed \\ Department of English \\ College of Education for Women, University of Baghdad, Baghdad, Iraq \\ Corresponding Author: Wafaa_1972@yahoo.com
}

Received: 10/15/2021

Accepted: 11/15/2021

Published:12/15/2021

\begin{abstract}
Aggression is a negative form of an anti-social behavior. It is produced because of a particular reason, desire, want, need, or due to the psychological state of the aggressor. It injures others physically or psychologically. Aggressive behaviors in human interactions cause discomfort and disharmony among interlocutors. The paper aims to identify how aggressive language manifests itself in the data under scrutiny in terms of the pragmatic paradigm. Two British literary works are the data; namely, Look Back in Anger by John Osborne (1956), and The Birthday Party by Harold Pinter (1957). This paper endeavors to answer the question of how aggressive language is represented in literature pragmatically? It is hoped to be significant to linguistic and psychological studies in that it clarifies how aggression is displayed in human communications linguistically. Qualitative and quantitative analyses are conducted to verify the findings. It ends with some concluding remarks, the most important of which are: insulting, belittling, ridiculing and threatening are prevalent speech acts; simile, hyperbole, metaphor and repetition appear due to Grice's maxims breaching while the use of taboo words, calling names, or abusive words are the impoliteness strategies that are distinguished in the data.

Keywords: aggression, literary plays, Look Back in Anger, Grice maxims, pragmatics, The Birthday Party, types of communication

Cite as: Kadhim, H.A., \& Mohammed, W. S. M. (2021). Aggressive Language in Literature: A Pragmatic Approach. Arab World English Journal, 12 (4) 224-242.

DOI: https://dx.doi.org/10.24093/awej/vol12no4.16
\end{abstract}




\section{Introduction}

Both Look Back in Anger of Osborne (1956), and The Birthday Party of Pinter (1957) are images of how the dominant, powerful British society declined after the world wars (Smith, 1986). This decline is related to reasons like losing jobs, food, houses, lovers and family members. These instances affect people's feeling of peace or being secured, and safe (Carter \& McRae, 2001). This means that the bad and difficult conditions were reflected on human interactions. Consequently, there was a real damage in individuals' behaviors and relationships. As it is assumed that literary works are representations of society, this research paper endeavors to scrutinize how aggression is manifested pragmatically in personal communications as literature portrays them. Aggression is argued to be a prevalent phenomenon in such interactions. Thus, it needs to be investigated so as to unravel how it is conveyed. In this case, people would be aware of it in terms of production, or recognition. The personal and social identity as well as people's relationships can be damaged if aggressive language is not displayed and explained to the public. Here lies the importance of studying this phenomenon as it is portrayed in the literary works chosen for the analysis.

\section{Literature Review}

Many scholars have studied how aggression and violence are found in many literary works. Malkin (1992), for instance, investigated verbal violence in many contemporary dramatic works. The focus, however, was not on the linguistic representations of aggression nor was it on the pragmatic strategies that convey it. Moreover, no careful attention has been paid in those works to the non- verbal representation of aggression since it can be verbal and non-verbal. The first is represented via words and causes psychological hurt whereas the second can be realized by acts like shouting, yelling, ignoring, throwing things and the like (Bayer \& Cegala, 1992). It is thought that aggression has been a feature of personal communication in most societies. As a negative behavior, it should be studied so as to preserve the physical and psychological state of people and render their social communication harmonious and smooth.

\section{Communication Styles}

Communication is a reciprocity process of transforming information among individuals via words or signs (Hemavathy \& Devi, 2016). Bocar (2017) argued that any message is conveyed accurately according to the person's behavior, attitude or thought verbally or non-verbally. Nielsen (2008) distinguished four communicative styles: aggressive, passive, assertive, and passive-aggressive. Aggressive communication means taking care of one's rights and disregarding others' rights. It is disruptive because it generates dissatisfaction and causes disharmony (Hemavathy \& Devi, 2016, p. 119). An aggressive communicator is close-minded and he cannot listen to others; he is poor to conceive others' points of view (Bocar, 2017, p. 3). For example, 'Your time is not important to me, just do as I say' (Nielsen, 2008, p.67). This indicates how the speaker does not respect others and dominates them. Passive communication involves taking care of the rights of others in a manipulative manner. The characteristics of a passive communicator make him indirect or weak in speaking up (Bocar, 2017, p. 3). No concern is given to the person's wants, needs, desires, or opinions, e.g., 'My mother always shouts at me, it is part of her personality' (Nielsen, 2008, p. 68). Assertive communication takes care of one's rights with considering the rights of others (Nielsen, 2008, p. 65). It is the clear, honest, and direct expression of the individual's needs, desires, thoughts, and feelings (Hemavathy \& Devi, 2016, p.119). Here, the communicators are concerned with maintaining the right, and integrity of others, and 
themselves in respectful attitudes. For example, 'That may be true, but I'm not interested at the moment' (Nielsen, 2008, p. 70). Passive-aggressive communication considers the rights of others at the expense of the speaker (Nielsen, 2008, p. 65). The communicators may feel angry, and helpless, but they behave in an indirect way of hostility; e.g., 'Mum, what do you think I am? Stupid?' (Nielsen, 2008, p. 70).

\section{Aggression}

Aggression has been defined from different perspectives. The behaviorists define it as a response that inflicts harm towards the receivers; a response that consists of noxious stimulus to another organism (Buss, 1961, p. 1). The social-psychological field defines aggression as any behavior that is intentionally achieved to harm another person besides the awareness of the target person to avoid harm (Anderson \& Bushman, 2002, p. 28). The psychological field identifies it as a behavior that is unrelated to emotional, or mental features (Warburton \& Anderson, 2015, p. 373).

\section{Motivations of Aggression}

Aggression is regarded as a problematic social phenomenon. Infante et al. (1984, p. 77), however, state that there are some causes for aggressive behaviors. Frustration is generated due to the hostility that results from disillusionment. Social learning can cause aggression when an individual learns aggressive actions from another character by observing his behavior. For example, a child who always watches aggressive cartoons may behave aggressively with others because he imitates others' behaviors unconsciously. Argumentative skill deficiency is the major reason for verbal aggression (Infante et al., 1989, p. 5). It is the lack of individuals' verbal skills in that they cannot deal with some issues which lead them to social conflicts. Moreover, aggression is triggered by other causes such as seeking safety, feeling of belongingness, selfesteem, self-confidence, or achieving needs, and building self-actualization (Lozovska \& Gudaite, 2013, p. 361). As such, aggression is defined in this paper as any disharmonious form of communication among interlocutors which is a consequence of previous reasons or causes. It is an unsuccessful kind of communication that is realized by verbal, and/or non-verbal acts causing psychological, or physical harm as well as dissatisfaction.

\section{Pragmatic Context}

Pragmatics is related to the implicated meaning, and what surrounds it (Leech, 1983, p.1). According to Widdowson (1996, p. 61), it implies the meaning that contributes to the source of communication as an attempt to connect the thoughts of users to their needs in a specific context. Hymes (1974, p. 55-63) classifies the features of context into: situations, participants, ends, act sequences, keys, instrumentalities, norms, and genres. Those factors are important in specifying meaning in human interactions. Many pragmatic theories can be utilized to grasp meaning. This research is concerned with three of them: speech acts, cooperative principles, and impoliteness strategies. They are the pragmatic issues that are chosen to scrutinize the aggressive language in the data under investigation.

\section{Speech Acts}

Language in society aims at strengthening the interrelated pivots of communication among users so as to have a clear mutual correspondence. It is proposed that there are three types of acts for any utterance. The locutionary act (literary meaning), illocutionary act (pragmatic meaning), 
and perlocutionary act (effective meaning) (Austin, 1962, p. 102). Saying is performing speech acts; it is the essence of Austin's work (Searle, 1969, p. 16). Speech acts are divided into five macro-categories that depend mainly on what speakers typically do (representatives, commissives, directives, expressives, and declaratives). These acts are further classified into other micro categories. They are differentiated by their felicity conditions (propositional, preparatory, sincerity, and essential conditions). For instance, promising is a micro speech act that belongs to the commissives.

\section{Cooperative Principle}

The cooperative principle, proposed by Grice (1975), is essential in natural communication. It has four pragmatic maxims; quantity (keep specific information), quality (saying things with evidence), relation (giving related information), and manner (involving well-sequences). If parties do not follow the same order in each conversation, these maxims are breached via violating, opting-out, flouting and infringing a maxim (Grice, 1975, p. 45). In this respect, breaching any maxim, a figure of speech may result such as metaphor, hyperbole, repetition, and so on (Grice, 1989, p. 34). Repetition, or tautology where a speaker repeats a sentence, phrase, or word for emphasis as in 'A man is a man' is one example of breaching the quantity maxim (Cuddon, 2013, p. 712). Breaching the maxim of quality, for instance, gives a metaphor which is a comparison between objects and people of some similar features (Wales, 2001, p. 250). A simile is a figure of speech that is used to make a comparison between two, or more different things to enhance or clarify an image; it is realized by the use of 'as, like, just' (Cuddon, 2013, p. 657). Cutting (2002, p. 37) states that hyperbole is a form of meaning that has an additional expression, exaggeration, or manipulation.

\section{Impoliteness}

Culpeper (1996) introduced the theory of impoliteness which is based on Brown \& Levinson's (1987) politeness theory; he argued that understanding impoliteness is impossible without recognizing politeness (Culpeper, 1996, p. 356). Impolite behaviors represent disharmony in communication in social interactions (Culpeper et al., 2003, p. 1546). In later works, Culpeper (2005, p. 38) defined impoliteness in that it "comes about when: 1) the speaker communicates face-attack intentionally, or 2) the hearer perceives, and/or constructs behavior as intentionally face-attacking, or a combination of (1) and (2)". The hallmark of the impoliteness model is that it is based on a real analytical framework because Culpeper worked on the real verbal and written data of impolite behaviors (Mullany \& Stockwell, 2010, p.72). Culpeper (1996, p. 356) identified some impoliteness strategies. Here are the relevant ones to this work:

1. Bald-on-record impoliteness: the face-threatening act is produced in a direct, clear, unambiguous and concise way; therefore, the circumstances of the face are irrelevant or minimized. In a nutshell, this strategy is used when the interlocutor intends to hurt others.

2. Positive impoliteness: it is the damage/attack to the hearer's positive face wants. The realizations of this strategy are: ignoring others deliberately, using abusive language (taboo words, swears), talking about inappropriate issues, and calling names, among others.

3. Negative impoliteness: it is the damage/attack to the hearer's negative face wants such as to frighten, scorn, or ridicule others.

4. Withhold politeness: it is the expected work of politeness to be unused, or absent (Culpeper, 1996, p.356- 358). 


\section{Model of Analysis}

The analytical framework of this study is based on the pragmatic tools that have been explained above. They are the speech act of Searle (1969), the cooperative principle of Grice (1975), and Culpeper's impoliteness theory (1996). It is worthy to remember that four macrospeech acts are included as declaratives are not expected to be found in the data. The breaching of any maxim may yield one figure of speech like metaphor, hyperbole, simile, and repetition. Impoliteness is concerned with the bald-on-record, positive impoliteness, negative impoliteness, and the withhold of politeness strategies. Thus, Figure one engineers the analytical framework of aggressive language in the literary works chosen for the analysis in this research.

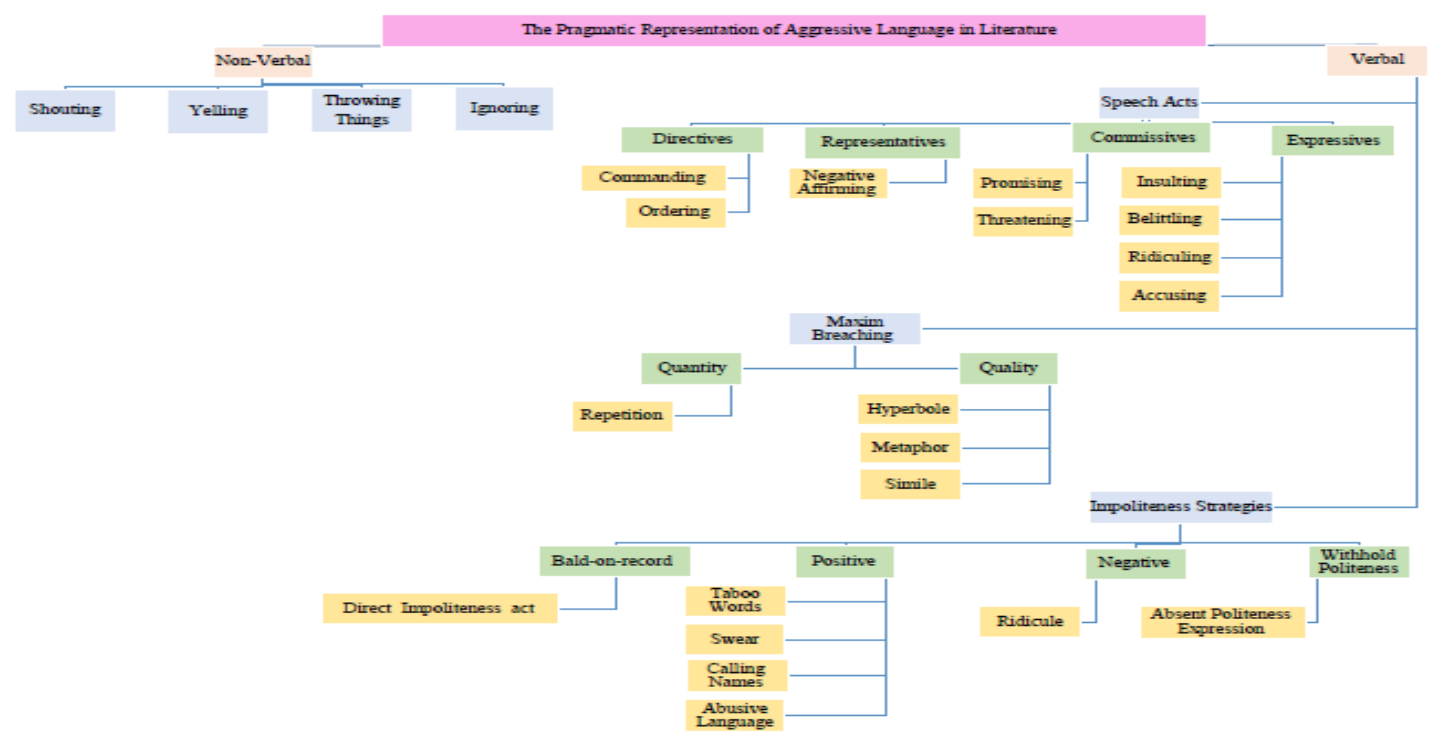

Figure 1. The Analytical Framework of Aggression in Literature

\section{Data and Analysis}

Two British plays from the same period, i.e., the fifties, are chosen to be the data of analysis in this research paper. The aim is find out how aggression is conveyed at that time in the British society. Some extracts are selected from each play to be part of the qualitative analysis whereas the other instances of aggressive language in the two plays are included in the quantitative analysis. Aggressive examples in each extract are underlined. It is worthy to mention that the unit of analysis in this paper is the utterance.

\section{The First Play Look Back in Anger}

Osborne's Look Back in Anger is characterized by its theme, and characterization that serve the purpose of the study (Osborne, 1978). It has three acts that reflect the British man's aggression towards others (Tecimer, 2005, p. 11). Jimmy is the hero of the play who represents the aggressive man in British society. He is unsatisfied with his job as an educated man because he thinks he deserves a better life. Jimmy is a villain character that has destructive actions directed towards his friend (Cliff) who lives with him and towards Jimmy's wife (Alison). Because of Jimmy's aggressiveness, his wife leaves him finally forever (Osborne, 1978). Here are some example extracts of aggression in this play. 


\section{Extract One}

Jimmy: Why do I do this every Sunday? Even the book reviews seem to be the same as last week's. Different books _ same reviews. Have you finished that one yet?

Cliff: Not yet.

Jimmy: I've just read three whole columns on the English Novel. Half of it's in French. Do the Sunday papers make you feel ignorant?

Cliff: Not 'arf.

Jimmy: Well, you are ignorant. You're just a peasant. What about you? You're not a peasant are you? (p.10).

Context: This conversation occurs between the three characters, Jimmy (the husband), Alison (Jimmy's wife) and their friend (Cliff) who lives with them. The husband is always angry as he shouts, insults, and ridicules his friend, his wife and her parents whether directly or indirectly. The reason behind his aggressiveness lies in his dissatisfaction with the life he leads.

Pragmatic analysis: When Jimmy says 'You are ignorant' ... 'You're just a peasant' he directs his words to his friend Cliff. Jimmy claims that he is the only educated person. Ignorant and peasant are aggressive words in communicating with friends. Hence, the utterance is an expressive act of insulting. According to Meibauer (2016, p. 157), the insulting act has the following felicity conditions: 1. Propositional content condition: the speaker's speech has an insulted function. 2. Preparatory condition: the speaker insults the hearer without motive for the insult or he may have one. 3. Sincerity condition: the speaker wants the hearer to feel insulted. 4. Essential condition: the speaker must affect the hearer to feel insulted.

On the other hand, 'you are ignorant' and 'You're just a peasant' are indirect speech acts towards Alison, Jimmy's wife. The husband always belittles Alison by saying abusive words. The context of the situation indicates that the italicized 'are' is a reference to injure Alison indirectly. The belittling act has the following felicity conditions (Mehdi, 2020, p.130): 1. Propositional content condition: the speaker assumes a negative aspect in the hearer. 2. Preparatory conditions: a. speaker holds that hearer is not important in terms of previous premises in speaker's mind, or aim. b. speaker believes that he can do so and has the power to give such unimportance to the hearer. 3. Sincerity conditions: a. speaker shows that the hearer is not important due to personal desire or belief on the side of the speaker. b. It is useful for the speaker to communicate that belittling. 4. Essential condition: speaker wants to communicate hearer's unimportance to others for a purpose or desire.

The positive impoliteness strategy is represented in this extract by the use of the swearing word 'peasant' in Jimmy's speech. Moreover, the aggressive phrase 'You're just a peasant' is a figure of speech of simile in terms of maxims breaching. In his utterance, Jimmy refers directly to Cliff and indirectly to Alison. Thus, Jimmy's behavior is in contrast with his claim of being an educated person as his words are full of aggression.

\section{Extract Two}

Cliff: Leave her alone, I said.

Jimmy: (shouting) All right, dear. Go back to sleep. It was only me Talking. Do you know? Talking? Remember? I'm sorry.

Cliff: Stop yelling. I'm trying to read. 
Jimmy: Why do you bother? You can't understand a word of it.

Cliff: Uh-huh.

Jimmy: you're too ignorant.

Cliff: Yea, and uneducated. Now shut up, will you?

Jimmy: Why don't you get my wife to explain it to you? She's educated. That's right, isn't it? (p.11)

Context: In this utterance, Cliff tries to protect Alison from Jimmy's aggressive behavior. However, Jimmy goes on shouting and yelling at his wife as a sign of disrespect as he thinks that she is uneducated and unattractive. Other people, however, find her educated and attractive.

Pragmatic analysis: In this utterance, both verbal and non-verbal acts appear. The contextual situation illustrates that 'shouting' and 'yelling' are non-verbal acts of aggression. While verbal behavior is represented by the expressive speech act of belittling. The utterance 'you're too ignorant' is a representative speech act of negative affirming (see Searle, 1969, p. 66 for the felicity conditions of affirming). According to Searle \& Vanderveken (1985, p. 15), each illocutionary act achieves the same point but in a different degree of strength with particular features that distinguish one verb from another. Affirming is usually performed to carry the positive assertion instead of the negative one; it differs from stating in that stating gives a full account of doing something and it is connected to the setting of something, or edification of the hearer (Searle \& Vanderveken, 1985, p 183). The other speech act here is that of ridiculing which is exemplified in saying 'She's educated'. Jimmy ridicules Alison because he considers her an uneducated woman. The ridiculing act has the following felicity conditions (Mehdi, 2020, p. 132): 1. Propositional content condition relates to the illocutionary force of the act which is an offense to the hearer. 2. Preparatory conditions: a. speaker specifies a moral, ethical or physical flaw in hearer, even if not real to some others. b. speaker has authority to issue such an act concerning hearer. 3. Sincerity conditions: speaker wants to present a negative picture of hearer to others. 4 . Essential conditions: producing the act counts as an attempt to offend hearer.

The positive impoliteness strategy is noticed here because Jimmy uses the abusive word 'too ignorant' to refer to Alison indirectly. The negative impoliteness strategy is exemplified in Cliff's utterance to Jimmy in saying 'shut up'. When Jimmy says 'she's educated', he ridicules the wife sarcastically. It is another form of negative impoliteness strategy.

\section{Extract Three}

Jimmy: Put the kettle on.

Cliff: Put it on yourself. You've creased up my paper.

Jimmy: I'm the only one who knows how to treat a paper, or anything else, in this house. Girl here wants to know whether her boyfriend will lose all respect for her if she gives him what he asks for. Stupid bitch. (p.12-13)

Context: Jimmy wants Cliff to make some tea for him. The latter refuses because he is upset by the act of creasing the paper. Jimmy sees himself as the only one who can deal with paper. $\mathrm{He}$ refers to his wife aggressively but indirectly. 
Pragmatic analysis: Jimmy is addressing his friend in a directive speech act of ordering. The ordering act commonly occurs if one has power over others (Searle \& Vanderveken, 1985, p. 201). Thus, if it is compared with commanding; it differs and it has less authority. The felicity conditions of the ordering speech act can be outlined as follows: 1. Propositional condition: a future act by hearer which is in the benefit of speaker. 2. Preparatory conditions: a. Hearer is able to do this act. b. Speaker has the authority to issue such an act as far as hearer is concerned. 3. Sincerity condition: speaker wants hearer to do the future act. 4. Essential condition: producing the act counts as an attempt to get the hearer to do the act.

Aggressive language is realized here by the absence of politeness. Withholding politeness is an impolite act. The expressive speech act of belittling is used in this utterance to refer to Alison. The positive impoliteness is found because Jimmy uses the taboo word 'bitch' referring to the wife. The last turn reveals that Jimmy uses hyperbole to address Alison. He breaches the quality maxim when addressing his wife as 'Stupid bitch' because he has no evidence that she is as such. This metaphor refers to the wife.

\section{Extract Four}

Jimmy: Have you seen her brother?... I only met him once myself. He asked me to step outside when I told his mother she was evil-minded.

Cliff: And did you?

Jimmy: Certainly not. He's a big chap...Yes, that's the little woman's family. They're what they sound like: sycophantic, phlegmatic and pusillanimous.

Cliff: I'll bet that concert's started by now. Shall I put it on?

Jimmy: I looked up that.......

Cliff: What was that?

Jimmy: I told you — pusillanimous. Do you know what it means?...

Alison: God help me, ....

Jimmy: Why don't you? That would be something, anyway. But I haven't told you what it means

yet have I? (Picks up dictionary.) In fact, ... I quote Pusillanimous. Adjective. Wanting of

firmness of mind, of small courage, having a little mind, mean spirited, ... Behold the Lady

Pusillanimous. (Shouting hoarsely.) ... (p.21-22).

Context: This extract is between Jimmy and Cliff about Alison's family. Here, Jimmy talks badly about them. He says her mother is evil-minded. He uses many abusive words to describe Alison's family. Jimmy explains what those words mean as he intends to injure Alison. The situation is typically aggressive.

Pragmatic analysis: This example illustrates an expressive speech act of belittling. The abusive words used by Jimmy towards his wife's family are 'sycophantic, phlegmatic and pusillanimous'. Such words hurt feelings. Furthermore, he insistently gives the meaning of such words saying that 'Pusillanimous' means having a little mind or mean spirited, etc. By insisting on injuring Alison's feelings, Jimmy issues the representative speech act of negative affirming. According to his opinion, she is unimportant and having low status. The use of the non-verbal act is realized by 'Shouting hoarsely'. Shouting at others causes fear to most people. It is an act of disrespect and humiliation. The positive impoliteness strategy is observed in the use of these taboo words which 
attack the wife's positive face. The repetition of these abusive words counts as an exaggeration to give a hyperbolic sense.

\section{Extract Five}

Jimmy: Helena, have you ever watched somebody die? No, don't move away. It doesn't look dignified enough for you.

Helena: If you come any nearer, I will slap your face.

Jimmy: I hope you won't make the mistake of thinking for one moment that I am a gentleman. (p. 56-57).

Context: Jimmy talks to Helena, his wife's friend, asking her if she has seen someone dying in front of her. This ironic question makes her angry and she says to him 'I will slap your face'. Again, the extract is characterized by aggression.

Pragmatic analysis: The aggressive language is represented because when Jimmy uses the word 'die', he is threatening Helena indirectly. It is a commissive speech act of threatening. According to Al Shamiri \& Abbas (2016, p. 11), the threatening act meets the following conditions: 1. Prepositional content condition: the preposition of threat should base on the future act, and be uttered in a specific situation. 2. Preparatory conditions: the addresser has to know that the act is not preferable by the addressee. 3. Sincerity condition: the speaker's intention to carry out the act of threatening is serious. 4.Essential conditions: the addresser insists on making the addressee does the act in virtue of his authority over the addressee. 'I will slap your face' is another threatening act by Helena. When he says that he is not a gentleman, he admits his aggressiveness by issuing this representative speech act of negative affirming. Jimmy says that he is not a 'gentleman' which acknowledges his aggression. This counts as a threatening act in that he can easily hurt others as he is not a gentleman. The whole interaction is impolite as Jimmy's and Helena's negative faces are attacked, respectively. This sarcastic manner of using the word 'die' indicates carelessness and disrespect concerning others' life. It is a ridicule of the negative impoliteness strategy.

\section{Extract Six}

Jimmy: (to his wife) You don't believe in all that stuff. Why you don't believe in anything. You're just doing it to be vindictive, aren't you? Why- why are you letting her influence you like this?

Alison: Why, why, why, why! That's word's pulling my head off!

Jimmy: And as long as you're around, I'll go on using it (p. 54).

Context: The use of the word 'vindictive' proves that Jimmy treats his wife aggressively. The repetition of the word 'why' bothers the wife as if she is in a questioning session.

Pragmatic analysis: The utterance ' $I$ 'll go on using $i t^{\prime}$ is a commissive speech act of promising (see Searle (1969: 61) for its felicity conditions). He promises to use this way of questioning with his wife in all their future interactions. This act of promising has an aggressive implication. The use of the word 'vindictive' is impolite in that it destroys the positive face of Alison. 


\section{The Second Play The Birthday Party}

This play of Pinter (1957) starts on the morning of the alleged birthday and ends the next morning (Pinter, 2007, p. 1-3). Stanley is the nominal character of the play. Goldberg and McCann are the strangers who interrogate and intimidate Stanley (Pinter, 2007, p. 15). Even though they never actually realize what he has done. They intend to accuse him of murdering his wife and then they take him to Monty, an unrevealed thing in the whole play. Goldberg and McCann use aggression as a weapon to control Stanley and dominate him. Finally, their tormenting makes a mental breakdown to him (Carter \& McRae, 2001, p. 369). Verbal aggression in British society is exemplified in this play (Majhi, 2018, p. 1).

\section{Extract One}

Goldberg: A warm night.

Stanley: [turning.] Don't mess me about!

Goldberg: I beg your pardon?

Stanley: [moving downstage.] I'm afraid there's been a mistake. We're booked out. Your room is taken. Mrs. Boles forgot to tell you. You'll have to find somewhere else.

Goldberg: Are you the manager here?

Stanley: That's right.

Goldberg: Is it a good game?

Stanley: I run the house. I'm afraid you and your friend will have to find other accommodation.

Goldberg: (rising). Oh, I forgot, I must congratulate you on your birthday. (Offering his hand.) Congratulations.

Stanley: (ignoring hand). Perhaps you're deaf.

Goldberg: No... What a thing to celebrate-birth! Like getting up in the morning. ... Getting up in the morning, they say, what is it? Your skin's crabby, you need a shave, your eyes are full of muck, your mouth as like a boghouse, the palms of your hands are full of sweat, your nose is clogged up, your feel cheerful... (p. 30).

Context: In this extract, Goldberg initiates the utterance with greetings. Stanley does not answer appropriately because he is anxious and he never welcomes Goldberg's arrival. He tries to persuade Goldberg to leave the boarding house. Goldberg is aware that he is afraid, but he insists on showing his power over Stanley. Goldberg continues in ridiculing his social position, but the latter keeps resisting him.

Pragmatic analysis: Goldberg's greeting is not answered by Stanley. Thus, the withholding of politeness strategy appears. Stanley is humiliated by Goldberg's superiority over him from the first moment. The belittling expressive speech act is represented by Goldberg's utterance 'I beg your pardon'. It means that they are careless of Stanley's worries. The ridiculing expressive speech act is represented in the utterance: 'are you the manager?', said by Goldberg. Stanley behaves as the owner of the house and he tries to make Goldberg leaves the boarding house. 'Is it a good game?' is an expressive speech act of accusation because Goldberg uses his power to intimidate Stanley and he accuses him of committing the crime which is never explained clearly throughout the whole play. It is an alleged crime. The act of accusation meets the following felicity conditions (Ribeiro, 2012, p. 164-165): 1. Propositional content condition: The speaker predicates the hearer is responsible for the existence of a particular state of affairs. 2. Preparatory condition: 
The state of the affair is bad. 3. Sincerity condition: The speaker is aware of the other person's behaviors. 4. Essential condition: The hearer considers it as an accusation.

The ignoring acts are used by both speakers in the following turns: firstly; when Goldberg moves to congratulate Stanley, secondly; the latter does not respond. These are non-verbal aggressive behaviors. The word '...deaf' is abusive because it attacks the positive face of Goldberg. In the last turn, Goldberg goes on using abusive words and calling names referring to Stanley's life. They are unsuitable expressions that injure Stanley. According to the context, Goldberg insists on uttering abusive words that illustrate the representative speech act of negative affirming. The context reveals the exemplification of positive impoliteness strategy by attacking Stanley's positive face when Goldberg uses calling names. Goldberg compares the waking up of Stanley to his birthday party. This comparison is metaphorical in that Stanley is not prepared for his party. He says: 'Your skin's crabby, you need a shave, your eyes are full of muck, your mouth as like a boghouse, the palms of your hands are full of sweat, your nose is clogged up, your feel cheerful'. All these words describe the state of Stanley when he wakes up in the morning. This metaphor is aggressive as it causes uncomfortableness to Stanley.

\section{Extract Two}

Goldberg: Why did you never get married?

McCann: She was waiting at the porch.

Goldberg: You skeddadled from the wedding.

McCann: He left her in the lurch.

Goldberg: You left her in the pudding club.

McCann: She was waiting at the church.

Goldberg: Webber! Why did you change your name?

Stanley: I forgot the other one.

Goldberg: What's your name now?

Stanley: Joe Soap.

Goldberg: You stink of sin.

McCann: I can smell it. (p. 34).

Context: Goldberg and McCann use abusive language with Stanley in questioning him. They accuse him that he killed his wife. Then, they ask him why did not he get married. It is a confusing situation composed of a series of questions. They offend him indirectly to reach their goal of taking him with them to the Monty which is an organization that is unknown to him. They never give him a chance to answer. The utterances contain unsuitable expressions. They cause psychological harm to Stanley.

Pragmatic analysis: Disharmonious interaction characterizes this extract. The insulting speech act is realized when Goldberg and McCann use abusive words as: in 'porch' (which means she is a bad lady), 'skedaddled' (which means irresponsible), 'lurch' (meaning unstable), 'pudding club' (which is a bad place for a meeting), and 'stink of sin' (which means his sin has a particular smell that can be smelled). The positive impoliteness strategy is realized here because Goldberg and McCann call names against Stanley. The 'stink of sin' is a metaphor because they compare the sin to a perfume with a bad smell. 


\section{Extract Three}

McCann: Who are you, Webber?

Goldberg: What makes you think you exist?

McCann: You're dead.

Goldberg: You're dead. You can't live, you can't think, you can't love. You're dead. You're a plague gone bad. There's no juice in you. You're nothing but an odour! (p. 36).

Context: The use of successive rapid questions with Stanley is cruel and contemptible. They ask him in a way as if he is not a human being. They use the word 'who' which indicates an unknown person but they know him well. They show all meanings of aggression in their way of addressing Stanley.

Pragmatic analysis: The belittling expressive speech act appears here. The repetition of 'You're dead' realizes the negative affirming act in this extract. The context demonstrates the use of abusive words like 'exist, dead, can't live, can't think, can't love and nothing but an odour'. Goldberg and McCann injure Stanley's feelings, emotions, and social status. The negative impoliteness strategy is represented because of the use of ridiculous words that attack Stanley's negative face by Goldberg and McCann. The breaching of the quality maxim is realized because Goldberg has no evidence of ridiculing the victim's personality. Thus, the metaphorical expression appears in this utterance as Stanley is compared to a plague. 'You're dead' is repeated three times. This is breaching for the quantity maxim giving tautology.

\section{Extract Four}

Stanley: I told you to get those bottles out.

Goldberg: Mr. Webber, sit down a minute.

Stanley: Let me- just make this clear. You don't bother me...So why don't you just go, without any more fuss?

Goldberg: Mr. Webber, sit down.

Stanley: It's no good starting any kind of trouble.

Goldberg: Sit down.

Stanley: Why should I?

Goldberg: If you want to know the truth, Webber, you're beginning to get on my breasts.

Stanley: Really? Well, that's-

Goldberg: Sit down.

Stanley: No. (p. 45).

Context: McCann enters the house holding bottles but Stanley disagrees to get them in and he told him to leave them out. Goldberg and McCann start to interrogate aggressively repeating the sentence 'sit down' four times which demonstrates the carelessness for what Stanley suffers from.

Pragmatic analysis: 'Sit down a minute' indicates an ignoring behavior for Stanley's utterance. The repetition of 'sit down' represents a direct commanding speech act. According to Searle \& Vanderveken (1985, p. 201), this act has the characteristics of the directive force and authority performed over the hearer; it is mostly related to the institutional activity. It meets the following conditions: 1. Propositional condition: a future act is to be done which is beneficial for the speaker or hearer. 2. Preparatory condition: the speaker has the power over the hearer to ask him 
do the act and the speaker believes that the hearer has the ability to do it. 3. Sincerity condition: the speaker wants the hearer to do the act. 4. Essential condition: counts as an attempt to get the hearer to do the act. Repeating the sentence 'sit down' is a negative affirming speech act that hints to aggressive insistence with the aim of annoying the hearer. These acts push Stanley to struggle with Goldberg and McCann. 'You're beginning to get on my breasts' is a threatening speech act by Goldberg. The bald-on-record impoliteness strategy is observed because the aggression is obvious when they continue dominating their power over him. The repetition of the same phrase 'sit down' breaches the quantity maxim.

\section{Extract Five}

Goldberg: Do you recognise an external force?

Stanley: What?

Goldberg: Do you recognise an external force?

McCann: That's the question!

Goldberg: Do you recognise an external force, responsible for you, suffering for you?

Stanley: It's late.

Goldberg: Late! Late enough! When did you last pray?

McCann: He's sweating!

Goldberg: When did you last pray?

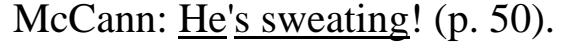

Context: Goldberg and McCann use the recycling way in their interrogation with Stanley. This is the most common way of speaking with him throughout the whole play. They ask him about the prayer time and they accuse him of sweating. They destroy Stanley and finally make him collapse.

Pragmatic analysis: The threatening speech act is represented by 'do you recognize an external force?' with the negative affirming act because Goldberg repeats this sentence many times and he does not give Stanley a chance to speak. The context refers to the use of aggressiveness because of treating Stanley badly. The repetition of the questions in the conversation is one of the flouting of quantity maxims.

\section{Extract Six}

Goldberg: We'll make a man of you.

McCann: And a woman.

Goldberg: You'll be re-orientated.

McCann: You'll be rich.

Goldberg: You'll be adjusted.

McCann: You'll be our pride and joy.

$[\ldots]$

Goldberg: A statesman.

McCann: You'll own yachts.

Goldberg: Animals.

McCann: Animals. [GOLDBERG looks at MCCANN.]

Goldberg: I said animals.

[...] 
Stanley: Uh-gug...uh-gug...eeehhh-gag...[On the breath.] Caahh...caahh... [They watch him. he draws a long breath which shudders down his body. He concentrates.]

Goldberg: Well, Stanny boy, what do you say, eh? [They watch. He concentrates. His head lowers, his chin draws into his chest, he crutches.](p. 92-93)

Context: This is the last conversation with Stanley. Goldberg and McCann use sarcastic language that affects Stanley negatively. He becomes unstable and cannot breathe. He cannot even say a clear word.

Pragmatic Analysis: The first turns of Goldberg and McCann illustrate the use of utterances like (be rich, our pride and joy, statesman and own yachts) that indicate unreal acts alleged to be done to Stanley. Besides, other utterances like (make you a man, woman, re-orientated, animals) show the aggressive treatment to Stanley. Here, the ridiculing speech act is found. The repetition of the use of the word 'animals' means issuing an affirming speech act, but it has a negative sense in that it annoys the hearer. The positive impoliteness strategy is realized by the use of 'animals' referring to Stanley as Goldberg and McCann use it. It is a word of calling names. The use of different forms of uninformative expressions indicates the flouting of quantity maxim which gives repetition.

\section{Statistical Analysis}

This section depends on the previous qualitative analysis of the data. Mainly, it concentrates on quantitative analysis to provide clear findings of the pragmatic study. It illustrates the most prevalent forms of aggression that are realized in the two plays. The results are presented below. Figure Two shows the non-verbal acts in the two plays. They are ignoring, shouting, yelling, and throwing things with the highest percentage to ignoring. This non- verbal act is painful if used between family members, or friends. It has the highest appearance, which indicates that it is effective in showing passive-aggressive feelings towards others.

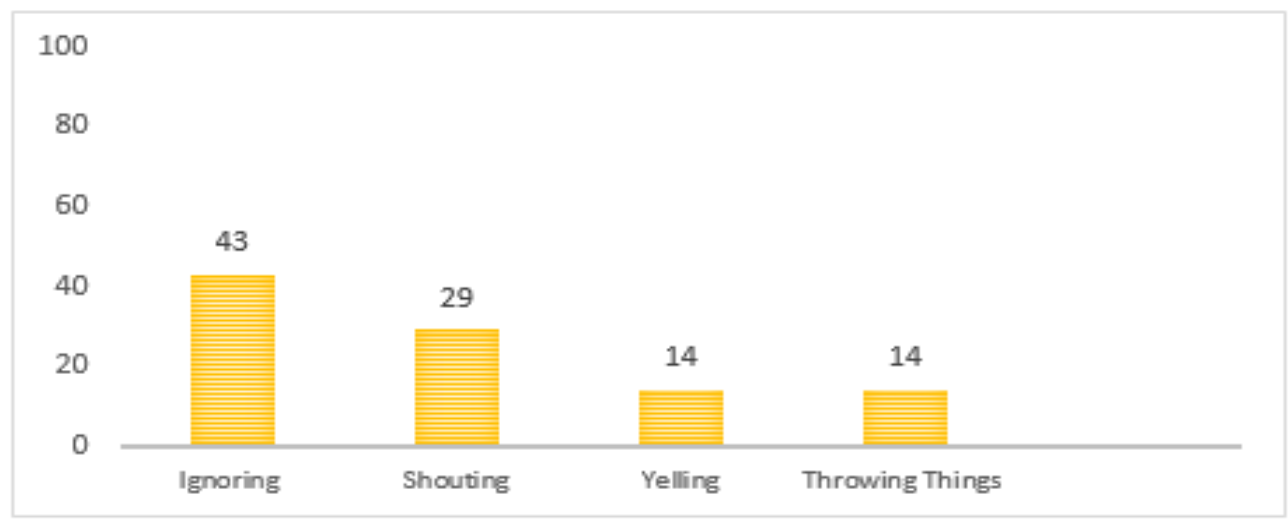

Figure 2. Non-verbal Acts in the Two Plays

Figure Three represents the macro types of speech acts that are issued in the two plays with the highest percentage to expressive speech acts. Then, representatives, commissives, and directives come respectively. Since the expressive acts represent the aggressive behavior of the aggressor, it is natural to be the highest in appearance. 


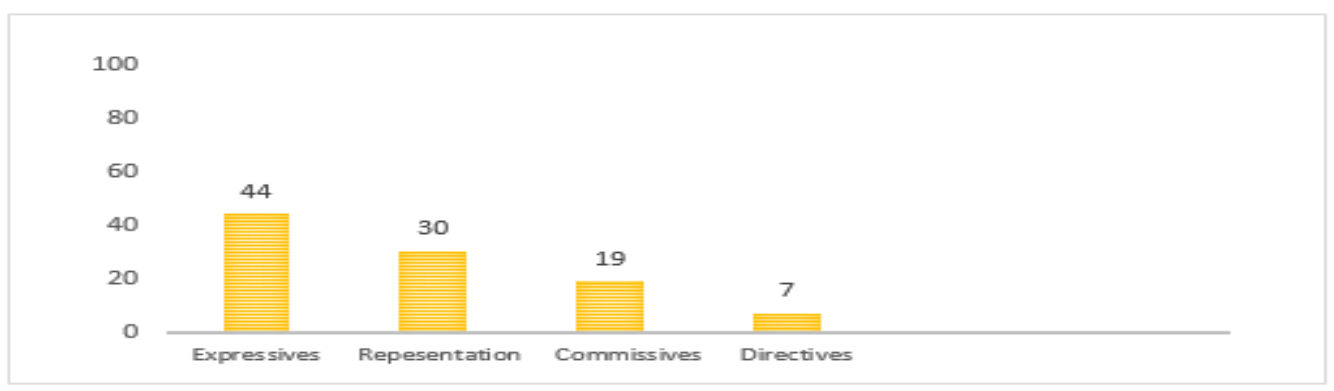

Figure 3. Macro Speech Acts in the Two Plays

Figure Four demonstrates the micro speech acts for the two plays. The higher one is a negative affirming speech act. They are arranged from highest to lowest as follows: belittling, threatening, ridiculing, insulting, commanding, promising, ordering, and accusing. The affirming speech act is aggressive if it is repeated again and again which shows disrespect and causes annoyance to the receiver. This is why it has been called as a negative speech act.

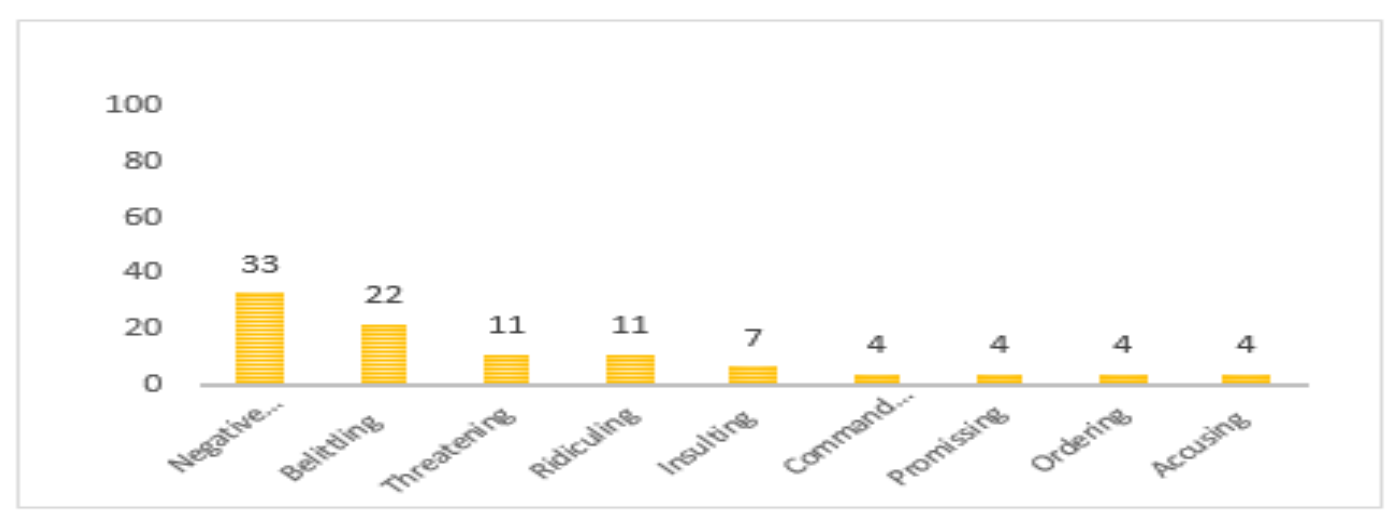

Figure 4. The Sub-types of Speech Acts in the Two Plays

Figure Five illustrates the figures of speech that are utilized in the two plays. They are respectively: repetition, metaphor, hyperbole, and simile. Repetition is annoying as well; it causes nervousness during personal conversations.

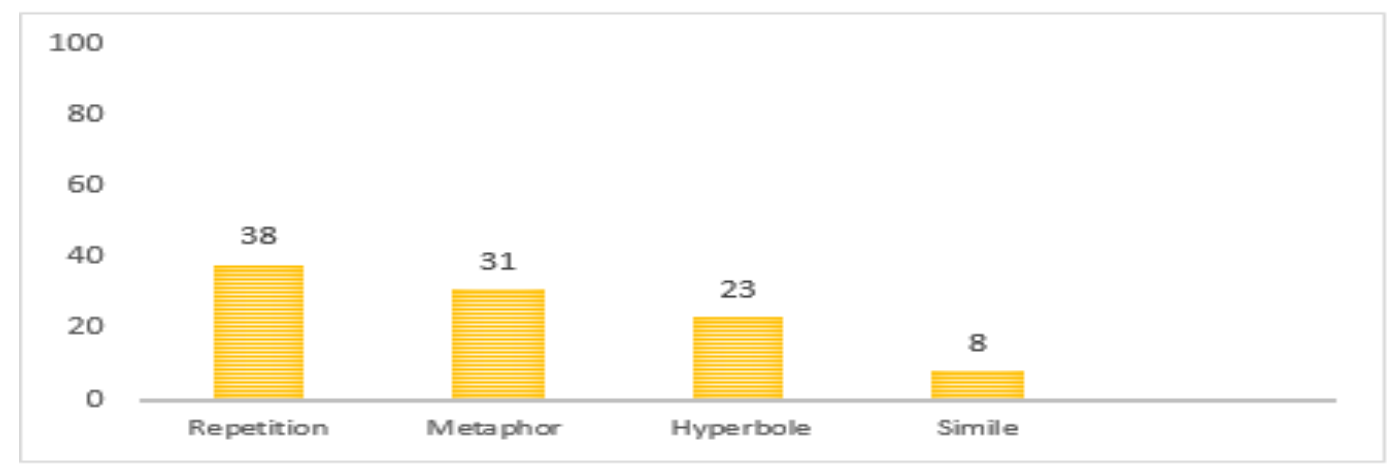

Figure 5. Figures of Speech in the Two Plays 
Figure Six displays the four types of impoliteness strategies. The positive impoliteness strategy takes the highest percentage, whereas the negative, withholding, and bald-on-record impoliteness strategies are observed respectively. Positive impoliteness is the highest because normally human beings like to be respected and valued, especially in familial, or intimate relations.

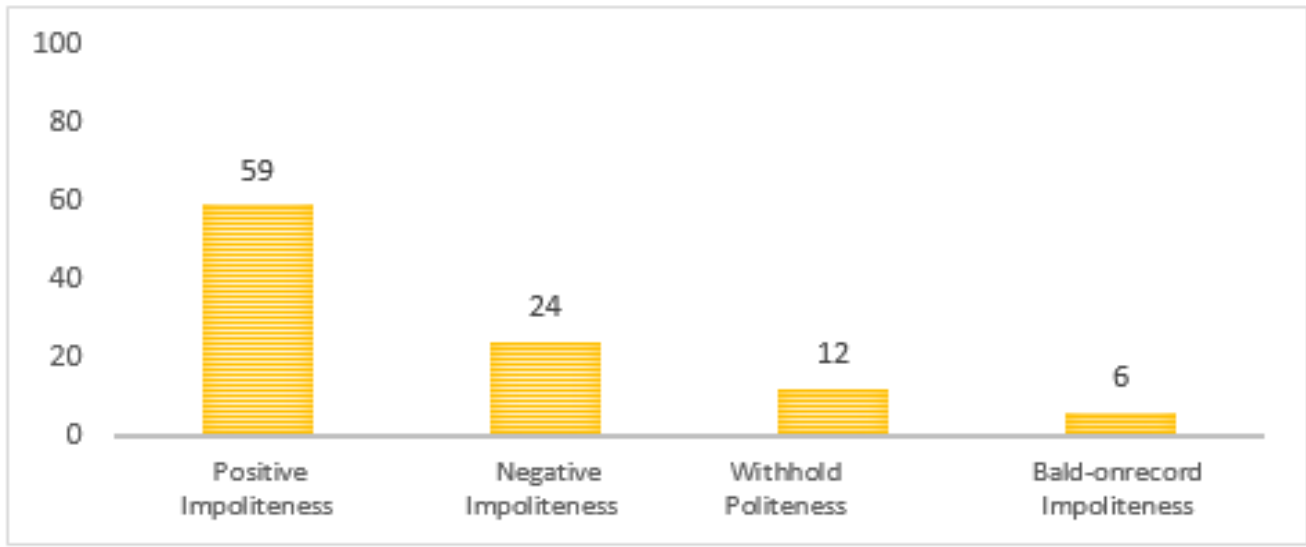

Figure 6. Impoliteness Strategies in the Two Plays

Figure Seven reports the micro impoliteness strategies in the two plays. It is observed that some of them appear in the use of language. Calling name is the most prevalent one, then ridicule, taboo words, absent politeness expression, abusive language, swear, and direct impoliteness acts are realized respectively. It seems that calling others names is the easiest way of showing one's aggression towards others.

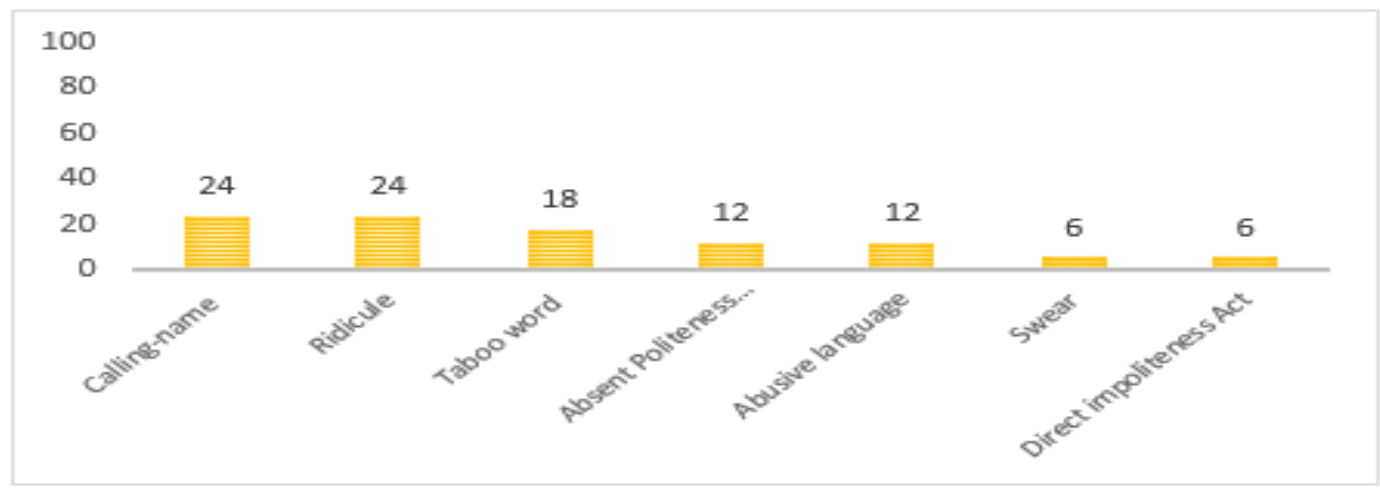

Figure 7. The Micro Impoliteness Strategies in the Two Plays

\section{Discussion}

Based on what has been mentioned above, aggression characterizes the data under analysis in both verbal and non-verbal forms. It is manifested verbally via different pragmatic phenomena. Expressive speech acts are the highest in appearance. The affirming speech act which is used in a negative way imparting an annoying sense appears as the highest in percentage. Many figures of speech are used. The annoying repetitive pattern shows the highest percentage. Most of the impoliteness strategies are directed to threaten the positive face of the interlocutors. The aggression phenomenon is prevalent in interpersonal relations with a harmful effect on human beings and their relationships. 


\section{Conclusions}

The concluding remarks this study reveals are presented as follows:

1. Aggression is caused by specific reasons like close-mindedness, misunderstanding, hostile or rude attitudes as well as the psychological state of the interlocutors.

2. Many pragmatic strategies are used to convey aggression. Speech acts and impoliteness are the most prevalent ones in the data under scrutiny.

3. The two plays show the highest frequency for the expressive speech act which is an indication of expressing the aggressive self of the speakers because aggression is an inner feeling and behavior that is expressed via language.

4. Aggressive people utilize different figures of speech to show their aggression in personal communication.

5. Impoliteness is an inherent feature in aggressive communications. The positive impoliteness strategy is the highest which means that people need harmonious interactions with others. They usually do not prefer clashing with their partners, or friends.

6. Aggressive styles may lead to unwanted consequences if they abound in personal communications.

\section{Bio of Authors}

Wafaa Sahib Mehdi Muhammed (Ph.D.) is a faculty member at the University of Baghdad/College of Education for Women/ Department of English. Her major is pragmatics and critical studies. She has published more than twenty articles in local and international academic journals. ORCID: https://orcid.org/0000-0002-5506-9529

Hanan Abdul-kareem Kadhim is an MA student at the College of Education for Women/ Department of English. Her interest is in pragmatics and discourse analysis. ORCID: https://orcid.org/0000-0003-2613-5096

\section{References}

Al Shamiri, S. \& Abbas, I. J. (2016). The Speech Act of Threatening in English and Arabic with Reference to the Glorious Qur'an. University of Babylon.

DOI:10.13140/RG.2.2.35445.58084

Anderson, C. A., \& Bushman, B. J. (2002). Human aggression. Department of Psychology, Iowa State University, Ames, Iowa 50011-318.

Austin, J. L. (1962). How to Do Things with Words. Oxford: University Press.

Bayer, Ch. L., \& Cegala, D. J. (1992). Trait verbal aggressiveness and argumentativeness:

Relations with parenting style, Western Journal of $\quad$ Communication, 56-(3), 301-310, DOI: $10.1080 / 10570319209374418$. http://dx.doi.org/10.1080/10570319209374418

Bocar, A. C. (2017). Aggressive, Passive, and Assertive: Which Communication Style is Commonly Used by College Students? SSRN Electronic Journal.

DOI:0.2139/ssrn.2956807.https://www.researchgate.net/publication/316501048

Buss, A. H. (1961). The psychology of aggression. John Wiley \& Sons

Inc. https://doi.org/10.1037/11160-000

Carter, R., \& McRae, J. (2001). The Routledge History of Literature in English. London and New York: Psychology Press. 
Arab World English Journal (AWEJ) Volume 12. Number 4. December 2021

Aggressive Language in Literature: A Pragmatic Approach

Kadhim \& Mohammed

Cuddon, J.A. (2013). A dictionary of literary terms and literary theory (5th ed.). A $\quad$ John Wiley \&Sons, Ltd., Publication.

Culpeper, J. (1996). Towards an anatomy of impoliteness. Journal of Pragmatics 25 349-367.

Culpeper, J. (2005). Impoliteness and entertainment in the television quiz show: the weakest link. Journal of politeness research language behaviour culture.

DOI:10.1515/jplr.2005.1.1.35

Culpeper, J., Bousfield, D. \& Wichmann, A. (2003). Impoliteness revisited: With special reference to dynamic and prosodic aspects. Journal of Pragmatics 35:1545-1579.

Cutting, J. (2002). Pragmatics and discourse: a resource book for students. London and New York.

Hadiati, Ch. (2019). Felicity Conditions of the Speech Acts in Banyumasan Daily Conversation. Theory and Practice in Language Studies, Vol. 9, (No. 6), pp. 700-705. DOI: http://dx.doi.org/10.17507/tpls.0906.13

Hemavathy, V. \& Devi, S. S. (2016). Assertive communication. International Journal of Humanities, Arts, Medicine, and Sciences. Vol. 4, Issue 1, 119-126. $\quad$ www.bestjournals.in

Hymes, D. (1974). Foundations in Sociolinguistics: an Ethnographic Approach. Philadelphia: University of Pennsylvania Press.

Grice, P. (1975). Logic and Conversation. In P. Cole \& J. L. Morgan (Eds.), Syntax and Semantics. Vol. 3, (pp.41-58). New York: Academic Press.

Grice, P. (1989). Studies in the Way of Words. Harvard: Harvard University Press.

Infante, D. A., Chandler, Theresa A. \& Rudd, Jill E. (1989). Test of an Argumentative Skill Deficiency Model of Interspousal Violence. Communication Faculty Publications. https://engagedscholarship.csuohio.edu/clcom_facpub/55

Infante, D. A., Trebing, J. D., Shepherd, P. E., \& Seeds, D. E. (1984). The relationship of argumentativeness to verbal aggression. Southern Speech Communication Journal, 50- (1), 67-77, DOI http://dx.doi.org/10.1080/10417948409372622

Ladd, G. W. (2006). Peer Rejection, Aggressive or Withdrawn Behavior, and Psychological Maladjustment from Ages 5 to 12: An Examination of Four Predictive Models. Child Development, 77(4), 822 846. https://doi.org/10.1111/j.1467-8624.2006.00905.x

Leech, G. (1983). Principles of Pragmatics. New York: Addison Wesley Longman Publishing.

Lozovska, J. \& Gudaite, G. (2013). The Understanding of Aggression Motivation and the Psychotherapy Process. Procedia - Social and Behavioral Sciences. Vol. 82, Pages 360365. https://doi.org/10.1016/j.sbspro.2013.06.275

Majhi, N. (2018). Verbal violence and suppression of female characters in Harold Pinter's play the birthday party. UGC-approved journal. No. 48514, 7, 10.

Malkin, J. (1992). Verbal Violence in Contemporary Drama. Cambridge: Cambridge University Press.

Mehdi, W. S. (2020). American sexism: a critical pragmatic perspective. European

Journal of Literature, Language and Linguistics Studies. Vol. 4, (3). DOI: 10.46827/ej1ll.v4i3.225 www.oapub.org/lit

Meibauer, J. (2016). Slurring as Insulting. In R. Finkbeiner, J. Meibauer \& H. Wiese (Eds.) Pejoration (pp. 145-167). Amsterdam: John Benjamin Publishing Company.

Mullany, L. \& Stockwell, P. (2010). Introducing English Language: A Resource Book for Students. Nottingham: Routledge.

Nielsen, J. (2008). Effective communication skills. John Nielsen. United State. 
Osborne, J. (1978). Look back in anger: a play in three acts. London and Boston.

Ribeiro, H. J. (2012). Inside Arguments: Logic and the Study of Argumentation. Newcastle: Cambridge Scholars Publishing.

Pinter, H. (1960). The birthday party. New York: Grove Press.

Pinter, H. (2007). The Birthday Party. Gale. http://www.enotes.com/birthday-party/copyrig

Searle, J. R. (1969). Speech acts: An essay in the philosophy of language. University of California, Berkeley.

Searle, J. \& Vanderveken, D. (1985). Functions of illocutionary logic. Cambridge University Press.

Smith, H. L. Ed. (1986). War and Social Change: British Society in the Second World War. Manchester University Press.

Tecimer, E. (2005). The analysis of the theme of anger in John Osborne's plays: look back in anger, inadmissible evidence, watch it come down. Publish thesis.

Wales, K. (2001). A Dictionary of Stylistics (2nd ed.). England: Pearson Education Limited.

Warburton, W. A. \& Anderson, C. A. (2015). Aggression, Social Psychology of. Vol. 1, pp. 295299, DOI: 10.1016/B978-0-08-097086-8.24002-6.

Widdowson, H.G. (1996). Linguistics. Oxford: Oxford University Press. 